\title{
SPACE NUCLEAR POWER REQUIREMENTS FOR OZONE LAYER MODIFICATION
}

\author{
Thomas J. Dolan \\ Idaho National Engineering Laboratory \\ P. O. Box 1625 \\ Idaho Falls, ID 83415-1550 \\ (208) 525-5619
}

CAMERA READY MANUSCRIPT prepared for:

Ninth Symposium on Space Nuclear Power Systems

Albuquerque, New Mexico

12-16 January, 1992

12-16 January, 1992
initial submission: 14 June 1991
final submission: 15 October 1991

DE92 003278

Author to whom correspondence should be sent: T. J. Dolan

\section{DISCLAIMER}

This report was prepared as an account of work sponsored by an agency of the United States Government. Neither the United States Government nor any agency thereof, nor any of their employees, makes any warranty, express or implied, or assumes any legal liability or responsibility for the accuracy, completeness, or usefulness of any information, apparatus, product, or process disclosed, or represents that its use would not infringe privately owned rights. Reference herein to any specific commercial product, process, or service by trade name, trademark, manufacturer, or otherwise does not necessarily constitute or imply its endorsement, recommendation, or favoring by the United States Government or any agency thereof. The views and opinions of authors expressed herein do not necessarily state or reflect those of the United States Goverriment or any agency thereof. 


\title{
SPACE NUCLEAR POWER REQUIREMENTS FOR OZONE LAYER MODIFICATION
}

\author{
Thomas J. Dolan \\ Idaho National Engineering Laboratory \\ P.O. Box 1625 \\ Idaho Falls, ID 83415-1550 \\ (208) 525-5619
}

\begin{abstract}
This work estimates the power requirements for using photochemical processes driven by space nuclear power to counteract the Earth's ozone layer depletion. The total quantity of ozone $\left(\mathrm{O}_{3}\right)$ in the Earth's atmosphere is estimated to be about $4.7 \times 10^{37}$ molecules. The ozone production and destruction rates in the stratosphere are both on the order of $4.9 \times 10^{31}$ molecules/s, differing by a small fraction so that the net depletion rate is about 0.16 to $0.26 \%$ per year. The delivered optical power requirement for offsetting this depletion is estimated to be on the order of $3 \mathrm{GW}$. If the power were produced by satellite reactors at $800 \mathrm{~km}$ altitude (orbit decay time 300 years), some means of efficient power beaming would be needed to deliver the power to stratospheric levels $(10-50 \mathrm{~km})$. Ultraviolet radiation at $140-150 \mathrm{~nm}$ could have higher absorption rates in $\mathrm{O}_{2}$ (leading to production of atomic oxygen, which can combine with $\mathrm{O}_{2}$ to form $\mathrm{O}_{3}$ ) than in ozone (leading to photodissociation of $\mathrm{O}_{3}$ ). Potential radiation sources include $\mathrm{H}_{2}$ lasers and direct nuclear pumping of ultraviolet fluorescers.

\section{INTRODUCTION}

Recently the problem of depletion of the Earth's ozone has been receiving increased attention. The atmospheric ozone layer provides a useful service by absorbing most of the "Damaging Ultraviolet" radiation $(290-320 \mathrm{~nm})$ before it reaches the earth's surface. Without this protective layer, some animal and plant species would have difficulty surviving, and the incidence of human skin cancer and cataracts would be much greater (National Academy of Sciences 1979). A major effort has been launched to reduce emission of chlorinated fluorocarbons from aerosols and industrial processes. However, many other chemicals contribute to ozone depletion, such as hydrocarbons emitted by ruminants, bogs, and volcanoes. These sources will be difficult to curtail. It is worthwhile investigating the possibility of increasing the ozone production rate in atmosphere. The purpose of the present work is to estimate the power requirements for counteracting ozone depletion in the stratosphere using photochemical processes driven by space nuclear power.
\end{abstract}

\section{OZONE DYNAMICS}

\section{Production}

Ozone is produced mainly by the reaction

$$
\mathrm{O}+\mathrm{O}_{2}+\mathrm{M} \rightarrow \mathrm{O}_{3}+\mathrm{M}
$$



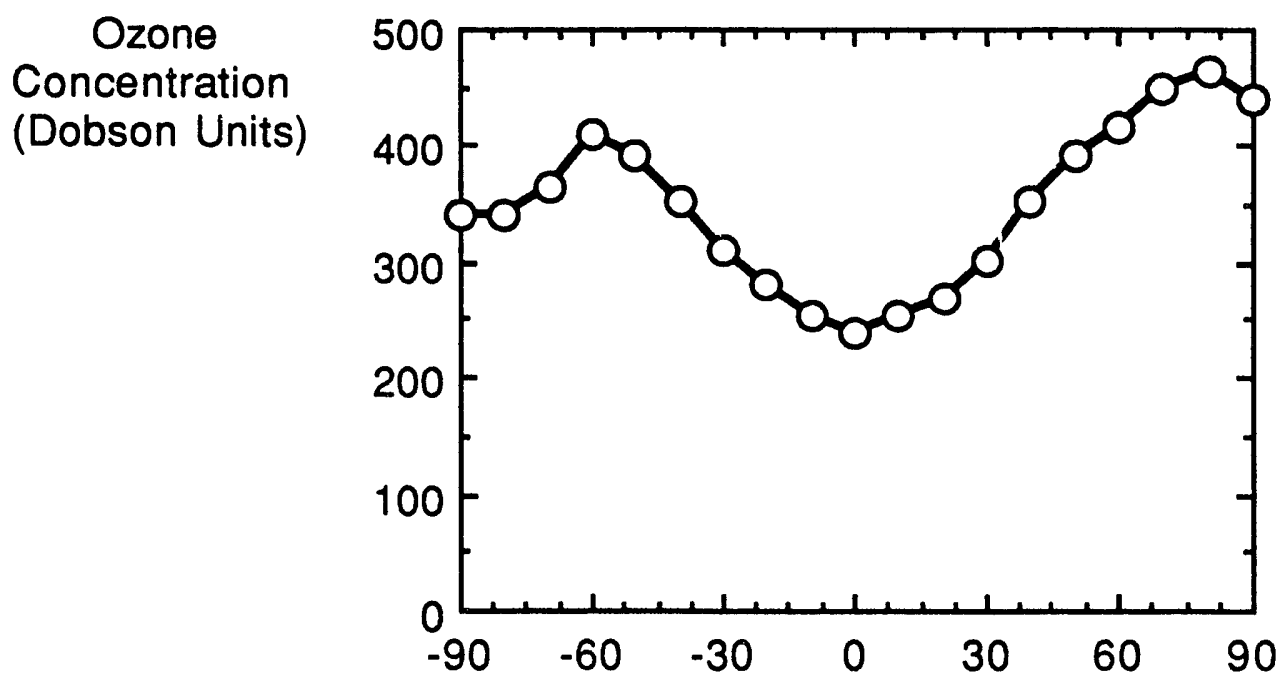

Latitude (degrees)

FIGURE 1. Variation of Longitudinally-Averaged Ozone Concentration with Latitude.

where $M$ is a third body required to carry away energy released by the combination reaction. The free oxygen atoms are produced mainly by solar radiation

$$
\mathrm{O}_{2}+\mathrm{h} v \rightarrow \mathrm{O}+\mathrm{O}
$$

in the stratosphere (altitude 11-50 km), and by

$$
\mathrm{NO}_{2}+\mathrm{hv} \rightarrow \mathrm{NO}+\mathrm{O}
$$

in the troposphere. (The troposphere is that part of the atmosphere below the tropopause, the height of which varies from $8-18 \mathrm{~km}$, with an average value of about $11 \mathrm{~km})$.

\section{Ozone Distribution}

According to April 1966 satellite data (Warneck 1988, Figure 3-2) the time-averaged ozone concentration in the northern hemisphere had three peaks at $70^{\circ}$ north latitude and $0^{\circ}, 110^{\circ}$, and $280^{\circ}$ longitude. In the southern hemisphere (October 1970 data) there was one broad peak at $60^{\circ}$ south latitude from $140^{\circ}$ to $200^{\circ}$ longitude. The concentrations varied from about 240 Dobson units at the equator to about 500 Dobson units at the peaks. (One Dobson unit $=2.69 \times 10^{20}$ molecules $/ \mathrm{m}^{2}$.) In order to estimate the total amount of ozone present in the atmosphere, we have computed the longitudinal-average concentration from those data. The result is shown in Figure 1. Taking into account the cosinusoidal variation of land area with latitude, we calculate the global average ozone concentration for this case to be 321 Dobson units, which is about 1.34 times the value at the equator.

The ozone concentration also varies with altitude $z$ above the earth's surface. We have made an approximate fit to the low-latitude experimental data (which have $\pm 25 \%$ variation about the median): 


$$
\begin{array}{ll}
\mathrm{n} \approx \mathrm{n}_{\max } \exp \left[-\left(\mathrm{z}-\mathrm{z}_{\max }\right)^{\left.2 / \mathrm{a}^{2}\right]}\right. & \mathrm{z}>10 \mathrm{~km} \\
\mathrm{n} \approx \mathrm{n}_{\mathrm{O}} & \mathrm{z}<10 \mathrm{~km}
\end{array}
$$

where $\mathrm{n}_{\max }=3 \times 10^{12}$ molecules $/ \mathrm{cm}^{3}, \mathrm{z}_{\max }=26 \mathrm{~km}, \mathrm{a}=9 \mathrm{~km}$, and $\mathrm{n}_{\mathrm{O}}=0.5 \times 10^{18} \mathrm{~m}^{-3}$ (based on data from Figures 3-3 and 3-5 of Reference 2). Integrating this low-latitude data vertically, we find

$$
\int_{0}^{\infty} \mathrm{dz} n(\mathrm{z}) \approx 6.84 \times 10^{22} \text { molecules } / \mathrm{m}^{2}=254 \text { Dobson units, }
$$

which is consistent with Figure 1. Assuming the global average value is 1.34 times as great, the total quantity of ozone in the earths atmosphere is given by

$$
\mathrm{N} \approx 1.34\left(4 \pi \mathrm{R}^{2}\right) \quad \int_{0}^{\infty} \mathrm{d} \mathrm{z} \mathrm{n}(\mathrm{z})=4.7 \times 10^{37} \text { molecules (ozone), }
$$

where $R=6.378 \times 10^{6} \mathrm{~m}$ is the earth's radius (perfect sphere model).

\section{Ozone Destruction}

It is desirable to minimize the ozone loss, in order to protect the world ecosystem and human health. Ozone is destroyed by photodissociation

$$
\mathrm{O}_{3}+\mathrm{hv} \rightarrow \mathrm{O}_{2}+\mathrm{O}
$$

(the free oxygen can produce more ozone, however), and by collisions with free oxygen

$$
\mathrm{O}+\mathrm{O}_{3} \rightarrow \mathrm{O}_{2}+\mathrm{O}_{2}
$$

The dominant destruction process in the stratosphere is now known to be

$$
\text { net: } \begin{aligned}
& \mathrm{X}+\mathrm{O}_{3} \rightarrow \mathrm{XO}+\mathrm{O}_{2} \\
& \mathrm{XO}+\mathrm{O} \rightarrow \mathrm{X}+\mathrm{O}_{2} \\
& \mathrm{O}+\mathrm{O}_{3} \rightarrow \mathrm{O}_{2}+\mathrm{O}_{2}
\end{aligned}
$$

where the catalyst $\mathrm{X}$ represents $\mathrm{H}, \mathrm{OH}, \mathrm{NO}, \mathrm{Cl}$ and $\mathrm{Br}$ compounds. Ozone is also lost from the stratosphere by transport downward to the troposphere, where additional destruction processes occur.

Modeling the ozone concentration involves following the atmospheric life cycles of molecules based on hydrogen, carbon, nitrogen, and halogens, including interactions with solar radiation, plants, soil, and water. These molecule groups control the concentrations of ozone-destructive catalysts. About 150 chemical reactions and photochemical processes involving 50 different species must be accounted for as functions of altitude, latitude and time. The approximate destruction rates of ozone by various catalyst processes are shown in Table 1.

Improved knowledge of reaction rate coefficients is gradually improving the ozone depletion estimates. According to a recent NASA Report (Watson et al. 1990), "The analysis of the total-column ozone data from ground-based Dobson instruments show measurable downward trends from 1969 to 1988 of 3 to $5 \%$... in the Northern Hemisphere $\left(30^{\circ}\right.$ to $64^{\circ} \mathrm{N}$ latitudes) in the winter months that cannot be attributed to known natural processes." This represents an average ozone deplection rate $\lambda=0.16$ to $0.26 \%$ per year. Here we assume $\lambda \approx 0.21 \% /$ year $=6.7 \times 10^{-11} / \mathrm{s}$. 
Table 1. Globally Integrated Stratospheric Loss Rates of Ozone by Various Reactions (from Warneck 1988 Table 3-4.)

\begin{tabular}{ll} 
Coss Rate & $\begin{array}{l}\text { Lostyst } \\
10^{6} \mathrm{~mole} / \mathrm{s}\end{array}$ \\
\hline $\mathrm{O}$ & 21.1 \\
$\mathrm{ClO}$ & 15.2 \\
$\mathrm{NO}_{2}$ & 27.5 \\
$\mathrm{OH}$ & 17.6 \\
& \\
& \\
Total & $81.4=4.9 \times 10^{31} \mathrm{molecules} / \mathrm{s}$ \\
\hline
\end{tabular}

\section{PROSPECTS FOR INCREASING THE OZONE LAYER}

\section{Reducing the Depletion Rate}

Ozone preservation may be accomplished by affecting either the source or depletion rates, using either chemical or electrical means. The main chemical technique for reducing the depletion rate would be international regulations on production of some ozone-destroying chemicals. If CFC production were cut by 90$100 \%$ in the year 2000, the chlorine concentration in the atmosphere would gradually decrease from about $5 \mathrm{ppb}$ (2000) to about $2 \mathrm{ppb}$ (2070), primarily by interaction with tropospheric $\mathrm{OH}$, and the ozone depletion rate would be significantly reduced.

We could also attempt to reduce the ozone destruction rate electrically, by ionizing or chemically altering the catalysts which destroy ozone, such as chlorine. The density of chlorine is about two orders of magnitude lower than the ozone density, so the required energy is potentially lower. However:

1. There are many different catalysts $\left(\mathrm{H}, \mathrm{OH}, \mathrm{NO}_{2}, \mathrm{ClO}, \mathrm{BrO}, \ldots\right)$. Although it may becoine technically feasible in the future to tune the energy sources to multiple frequencies to remove or deactivate many of these ozone-destroying catalysts, a way to do so with low energy cost is not yet apparent;

2. Efficient, tunable uv lasers do not exist; and

3. Even if a catalyst were altered (for example, by ionizing chlorine), the energy supplied to alter a molecule does not remove it from the atmosphere. Later, it might change back to its original form or to other hazardous forms by various chains of reactions.

A technique more immediately available would be to produce ozone electrically in the stratosphere, in an effort to increase the source term.

\section{Ozone Production}

Ozone can be produced by electrical discharges in air. (Some $\mathrm{O}_{2}$ molecules become dissociated into atomic oxygen, which then combines with $\mathrm{O}_{2}$ to form $\mathrm{O}_{3}$.) In the 
stratosphere we might use energy from a nuclear-powered or solar-powered satellite to enhance the dissociation of $\mathrm{O}_{2}$ molecules. In order to have an orbit decay time of 300 years, the satellite would need to have an initial altitude of about $800-900 \mathrm{~km}$. The energy would have to be transmitted down to the stratosphere, possibly by the following means:

1. As a beam of ultraviolet photons from a nuclear pumped lamp or laser beam, which could dissociate $\mathrm{O}_{2}$ molecules;

2. As a beam of radio waves at about $1.4 \mathrm{MHz}$, which could heat electrons by cyciotron resonance in the earth's magnetic field; and

3. By power-beaming to secondary stations in the stratosphere where the resulting electrical power could be used to produce ozone by an electrical discharge or by uv photon generation.

Assuming that the energy can be tuned so that it dissociates $\mathrm{O}_{2}$ but does not appreciably destroy $\mathrm{O}_{3}$, we will estimate how much energy would be required in order to make a significant contribution to global ozone production. The tuning problem is left for future study.

\section{Energy Required to Replace Destroyed Ozone}

The destruction rate of ozone molecules was shown in Table 1. The rate of change of the total quantity of ozone in the atmosphere may be represented by a simple equation

$$
\mathrm{dN} / \mathrm{dt}=\mathrm{S}-\mathrm{D} \approx-\lambda \mathrm{N}
$$

where the source rate $S$ and destruction rate $D$ are both about $4.9 \times 10^{31}$ molecules $/ \mathrm{s}$ (Warneck 1988 Tables 3-1 and 3-5). The slight difference between these rates gives rise to a gradual depletion of the ozone. The power required to counteract this depletion is

$$
P=W_{3}(-d N / d t)=W_{3} \lambda N
$$

where $W_{3}=$ the average energy required to produce one ozone molecule. Since dissociation of one $\mathrm{O}_{2}$ molecule produces two exygen atoms, which can produce two ozone molecules, the minimum energy required under ideal conditions would be about half the dissociation energy, or $2.6 \mathrm{eV}$. However, some of the atomic oxygen is lost via other reactions, so not all of it produces ozone. Some of the delivered power may also contribute to ozone destruction, so the effective energy requirement per net ozone molecule produced will be higher than the minimum. Here we will assume that $W_{3} \sim 6 \mathrm{eV}$. The delivered optical power required to counteract the assumed ozone depletion rate is

$\mathrm{P} \sim(6 \mathrm{eV} / \mathrm{molecule})\left(1.6 \times 10^{-19} \mathrm{~J} / \mathrm{eV}\right)\left(6.7 \times 10^{-11} / \mathrm{s}\right)\left(4.7 \times 10^{37}\right.$ molecules $)=3 \mathrm{GW}$. If the efficiency of coupling electrical power to chemical reactions (via an ultraviolet lamp, laser beam. electrical discharge, or radiowaves) were on the order of $30 \%$, then the electricai power required would be $\mathrm{P}_{\mathrm{e}} \sim 10 \mathrm{GW}$. Alternatively, electrical power production requirements could be minimized by using a nuclear pumped laser or fluorescer (Prelas et al., 1988). 


\section{Satellite Power Plant Requirements}

If nuclear reactors were used for a satellite power station, then the required radiator area would be

$$
A=P_{e}(1-\eta) / \eta \text { e } \sigma T^{4}
$$

where $\mathrm{P}_{\mathrm{e}}=$ electrical power $(\mathrm{W}), \mathrm{e}=$ surface emissivity, $\eta$ = efficiency of converting thermal to electrical power, $\sigma=5.67 \times 10^{-8} \mathrm{~W} / \mathrm{m}^{2} \mathrm{~K}^{4}$, and $\mathrm{T}=$ radiator temperature $(\mathrm{K})$. To produce $P_{e}=10 \mathrm{GW}_{e}$ with thermionic cells at $\eta=0.1$, with $\mathrm{T}=1000 \mathrm{~K}$ and $\mathrm{e}=0.8$, the required total radiator area $\mathrm{A}=2 \times 10^{6} \mathrm{~m}^{2}$.

If photovoltaic cells with efficiency $\eta$ were used for satellite power stations, then the required area with incident heat flux q would be

$$
\mathrm{A}=\mathrm{P}_{\mathrm{e}} / \eta \mathrm{q} \text {. }
$$

For an incident solar flux $q=1400 \mathrm{~W} / \mathrm{m}^{2}$ at efficiency $\eta=0.1$, the solar panel area required to produce $10 \mathrm{GWe}$ would be $A=7 \times 10^{7} \mathrm{~m}^{2}$, a factor of 35 higher than the radiator area for reactors with thermionic cells. Such a large area of photovoltaic cells would be cumbersome to launch, install, and maintain.

\section{CONCLUSION}

If an effective means of coupling electrical energy into ozone production could be achieved, the ozone depletion rate could be slowed significantly by about $3 \mathrm{GW}$ of delivered optical power. If space nuclear power with $10 \%$ conversion efficiency were used, the required area for heat rejection radiators would be on the order of $2 \times 10^{6} \mathrm{~m}^{2}$. Use of nuclear-pumped ultraviolet fluorescers should also be investigated.

\section{Acknowledgements}

I am grateful to D. M. Woodall and D. Buden for helpful discussions. This work was partially supported by the U.S. Department of Energy, Office of Energy Research, under Contract DE-AC07-76IDO1570。

\section{References}

Miller, A. S. and I. M. Mintzner (1986) "The Sky is the Limit: Strategies for Protecting the Ozone Layer", World Resources Institute Research Report \#3.

National Academy of Sciences (1979) "Protection against Depletion of Stratospheric Ozone by Chlorofluorocarbons," Washington DC.

Prelas, M. A., F. P. Boody, J. F. Kunze, and G. H. Miley (1988) "Nuclear Driven Flashlamps," Lasers and Particle Beams, 6(1): 25-53.

Warneck, P. (1988) Chemistry of the Natural Atmosphere, Academic Press, San Diego.

Watson, R. T., M. J. Kurylo, M. J. Prather, and F. M. Ormond (1990) "Present State of Knowledge of the Upper Atmosphere 1990: an Assessment Report," NASA Office of Space Science and Applications, Reference Publication 1242. 

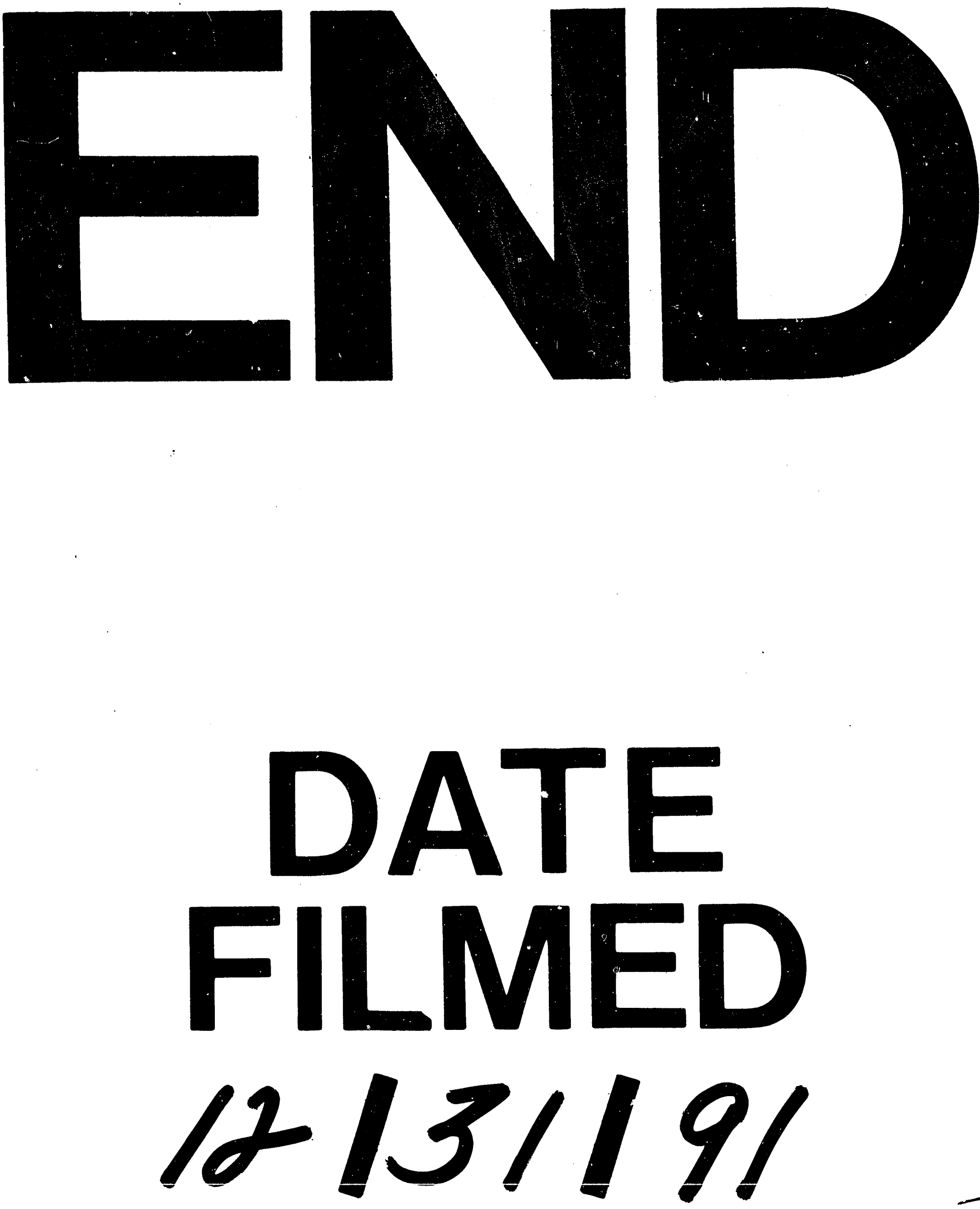
